\title{
Hubungan Self-Efficacy, Belief dan Motivasi dengan Kecemasan Mahasiswa dalam Pembelajaran Bahasa Inggris
}

\author{
Lufiana Harnany Utami, Linda Nurjati \\ UIN Sunan Gunung Djati Bandung, Jl. A.H. Nasution No. 105 Bandung \\ e-mail: lufiana2002@yahoo.com
}

\begin{abstract}
Anxiety about English is still felt in the learner at the college level, especially in dealing with reading sources in English. This study aims to see how individual factors (self-efficacy, belief, and motivation) effect the anxiety experienced by students in learning English. Research design use correlational research involving 100 students at UIN Sunan Gunung Djati Bandung from psychology faculty and faculty of education and teacher training. Sampling technique is using stratified random sampling. There are four instruments used which are Foreign Language Classroom Anxiety Scale, Children's Self-efficacy Scale, The Beliefs about Language Learning Inventory (BALLI) and motivation in learning english instrument. Data is analysed using statistic analysis of multiple regression. Results show that this each following variables which are self-efficacy, belief, and motivation has significant correlation with anxiety in learning English. Besides, there is also significant correlation between self-efficacy, belief, motivation and anxiety in learning English.
\end{abstract}

Keywords: anxiety, self-efficacy, belief, motivation, learning English

\begin{abstract}
Abstrak
Kecemasan terhadap bahasa Inggris masih tetap dirasakan pada pembelajar di tingkat perguruan tinggi terutama dalam menghadapi sumber bacaan dalam bahasa Inggris. Penelitian ini bertujuan untuk melihat bagaimana faktor individu (self-efficacy, belief, dan motivasi) berperan pada kecemasan yang dialami mahasiswa dalam pembelajaran bahasa Inggris. Rancangan penelitian menggunakan penelitian korelasional dengan melibatkan 100 mahasiswa UIN Sunan Gunung Djati Bandung dari Fakultas Psikologi dan Tarbiyah sebagai sampel. Penarikan sampel menggunakan stratified random sampling. Terdapat empat macam instrumen yang digunakan yaitu Foreign Language Classroom Anxiety Scale, Children's Self-efficacy Scale, The Beliefs about Language Learning Inventory (BALLI) dan motivation in learning english instrument. Teknik analisis data menggunakan analisis statistik regresi ganda. Hasil penelitian menunjukkan bahwa variabel self-efficacy, belief, dan motivasi masing-masing menunjukkan hubungan yang signifikan dengan kecemasan dalam pembelajaran bahasa Inggris. Demikian pula terdapat hubungan yang signifikan secara bersama-sama antara selfefficacy, belief, dan motivasi dengan kecemasan dalam pembelajaran bahasa Inggris.
\end{abstract}

Kata Kunci: kecemasan, self-efficacy, belief, motivasi, pembelajaran bahasa Inggris

\section{Pendahuluan}

Bahasa Inggris merupakan bahasa ilmu pengetahuan dimana mayoritas buku pegangan (textbook) yang digunakan mahasiswa khususnya di Universitas Islam Negeri Bandung pun berbahasa Inggris. Namun seringkali hal itu menjadi kendala bagi sebagian besar mahasiswa karena bahasa Inggris sendiri dianggap hal yang sulit dan menakutkan. Kemampuan memahami sumber dalam bahasa Inggris sebenar- nya menjadi keharusan bagi mahasiswa sejak mulai masuk ke perguruan tinggi tetapi kondisi yang ada banyak mahasiswa yang justru sangat memprihatinkan kemampuan bahasa Inggrisnya. Mereka lebih sering mencari buku yang sudah diterjemahkan dalam bahasa Indonesia atau menggunakan bantuan google translate agar bisa memahami materi perkuliahan yang diterima. Selain itu tuntutan akademik seperti membaca buku pegangan dalam 
bahasa Inggris juga dikeluhkan oleh para dosen karena mereka tidak dapat memberikan tugas membaca dalam jumlah yang banyak kepada mahasiswa. Pembahasan setiap bab dari buku yang digunakan seringkali disampaikan oleh dosen melalui perkuliahan yang berbentuk ceramah dan akhirnya dosen menyiapkan slide presentasi untuk dapat dipahami oleh mahasiswa. Apa yang seharusnya dilakukan oleh mahasiswa seperti membaca textbook, mendiskusikan dengan teman lainnya hingga melakukan presentasi menjadi terhambat karena untuk memahami materi pada setiap babnya membutuhkan waktu yang sangat lama.

Bahasa Inggris merupakan salah satu mata pelajaran yang dipelajari di bangku sekolah sejak sekolah dasar hingga universitas. Walaupun demikian, kemampuan bahasa Inggris siswa Indonesia masih rendah untuk berkomunikasi dalam bahasa Inggris baik secara lisan maupun tulisan. Dalam konteks pembelajaran bahasa Inggris dalam konteks Indonesia, pembelajar bahasa Indonesia memiliki motivasi yang rendah. Salah satu penyebabnya adalah ukuran kelas yang besar. Status bahasa Inggris sebagai bahasa asing membuat masyarakat Indonesia tidak menggunakan bahasa Inggris secara aktif dan meluas dalam komunikasi baik lisan maupun tulisan (Liando, Moni dan Baldauf, 2005). Siswa tidak memiliki pengalaman menggunakan bahasa Inggris dalam kehidupan sehari-hari mereka dan mereka tidak diharapkan dapat berbicara dalam bahasa Inggris dalam pekerjaannya di masa depan. Pembelajaran bahasa asing melibatkan faktor individu dan konteks sosial. Faktor individu meliputi motivasi, belief, risk-taking, anxiety dan intelegensi sedangkan konteks sosial berupa metode pengajaran, iklim kelas dan penilaian (Oxford, 1992). Menurut Pourdayaei (2013) faktor intelegensi, kemampuan kognitif, dan variabel afektif juga berkontribusi terhadap keberhasilan atau kegagalan pembelajaran bahasa. Young (1991) menjelaskan bahwa variabel afektif adalah salah satu faktor kritis yang berpengaruh dalam keberhasilan belajar bahasa asing. Siswa mengikuti kelas bahasa asing dengan berbagai keyakinan dan harapan yang dapat memengaruhi kemampuan mereka dalam mempelajari bahasa asing. Proses yang kompleks dari pembelajaran bahasa tidak dapat dijelaskan dari faktor kognitif saja karena untuk memahami proses pembelajaran, variabel afektif seperti motivasi, anxiety, dan risk taking perlu diteliti lebih dalam agar dapat dipahami beragam kondisi siswa.

Dunia pendidikan seringkali kurang menyadari bahwa berbagai keterampilan high-level cognitive yang diajarkan di sekolah seperti mengemukakan alasan (reasoning), mengambil keputusan (decision making) dan termasuk proses pembelajaran bahasa tidak terlepas dari emosi (Immordino-Yang dan Damasio, 2007). Kegiatan belajar melibatkan proses kognitif dan emosional secara simultan yang terjadi pada konteks sosial dan budaya. Neuroscience menjelaskan bahwa berpikir adalah proses emosi karena tanpa emosi individu menjadi tidak sensitif terhadap risiko, tidak sadar akan konsekuensi dan tidak mampu belajar dari pengalaman. Lebih lanjut dijelaskan bahwa area otak akan aktif saat individu merasakan emosi seperti kesenangan, ketakutan, marah, dan kesedihan. Dari alasan itu Immordino-Yang dan Damasio (2007) menyarankan para pendidik untuk memahami hubungan antara emosi dan kognisi sehingga dapat dengan baik mendesain lingkungan pembelajaran yang mendorong siswa menggunakan emosinya dalam menyelesaikan masalahmasalah akademik. Hubungan antara emosi dan kognisi datang dari berbagai penelitian neurobiology dan psychophysiology yang menyimpulkan bahwa induksi emosi karena stimulus lingkungan dapat menyebabkan perubahan mental. Immordino-Yang dan Damasio (2007) menyoroti hubungan antara emosi, kognisi dan fungsi sosial yang menghasilkan kerangka pikir tentang pentingnya emosi dalam pendidikan. Proses 
pembelajaran bahasa asing terkadang dapat menimbulkan pengalaman traumatis pada individu pembelajar. Banyak siswa yang merasakan kecemasan saat pembelajaran dalam kadar yang berbeda-beda. Linguistik terapan dan analisa psikologi meyakini bahwa ada faktor yang lebih mendasar daripada hanya pengajaran bahasa Inggris itu sendiri, yaitu affective factors. Motivasi dan kecemasan merupakan dua factor affective yang sangat berhubungan dengan keberhasilan dalam pembelajaran bahasa Inggris.

Motivasi merupakan salah satu affective factor dalam pemerolehan bahasa yang paling berpengaruh terhadap input dan intake bahasa pembelajar. Motivasi merupakan kunci keberhasilan dalam pembelajaran bahasa kedua dan bahasa asing dan itu adalah kombinasi dari usaha (effort) dan keinginan untuk mencapai tujuan yang ingin dicapai dengan sikapsikap yang mendukung untuk mencapai tujuan tersebut. Seperti yang diungkapkan oleh Gardner (2007) bahwa ketika seseorang termotivasi, dia akan memiliki alasan untuk terlibat dalam kegiatankegiatan yang relevan, melakukan usaha, dan tidak mudah menyerah, fokus pada tugas, menunjukkan keinginan untuk belajar dan menikmatinya, dan lain sebagainya. Tanpa motivasi tidak mungkin keberhasilan dalam pembelajaran dapat dicapai. Selain motivasi, kunci keberhasilan pembelajaran bahasa asing juga tergantung pada faktor kecemasan. Phillips (1992) mengatakan bahwa kecemasan dapat berpengaruh terhadap proses pembelajaran bahasa asing yang diikuti siswa. Kecemasan yang ada pada individu menjadi sumber ketidaknyamanan dalam kelas dan menyebabkan perasaan distress dan ketakutan sehingga dapat menghambat proses pembelajaran bahasa asing (Worde, 2003). Mulyana (2015) menambahkan bahwa individu yang memiliki kecemasan tinggi adalah mereka yang memiliki kekhawatiran yang berlebihan terhadap suatu hal. Menurut Casado dan
Dereshiwsky (2001) para peneliti sudah mempelajari pengaruh kecemasan terhadap pembelajaran bahasa asing sejak tahun 1970an namun tema kecemasan masih membutuhkan banyak penelitian karena meskipun metode dan teknik pengajaran terus berkembang, namun faktor kecemasan pada individu pembelajar tetap ada bahkan sampai pada tingkat universitas.

Konstruk kecemasan dalam pembelajaran bahasa asing dibuat oleh Horwitz, Horwitz dan Cope (1986) yang dijabarkan ke dalam tiga komponen yaitu ketakutan untuk berkomunikasi (communication apprehension), kecemasan terhadap tes yang ada (test anxiety), dan ketakutan terhadap penilaian yang negatif (fear of negative evaluation) diyakini bertanggung jawab atas pengalaman tidak nyaman dan reaksi emosi negatif pada siswa ketika belajar bahasa. Bahrien dan Ardianty (2017) juga mengatakan bahwa kecemasan merupakan respon alamiah yang dialami manusia namun jika tidak segera diatasi dapat mengganggu stabilitas fisik dan psikis. Beberapa gejala fisiologis umumnya berhubungan dengan kecemasan seperti tegang, gemetar, berkeringat, mulut kering dan jantung berdebar lebih cepat. Individu yang mengalami kecemasan dalam pembelajaran bahasa asing takut tidak mampu memahami pesan dalam komunikasi sehingga takut untuk berkomunikasi serta takut dinilai kurang mampu. Horwitz dkk. (1986) menjelaskan bahwa pendidikan bahasa asing adalah proses yang kompleks melibatkan persepsi pembelajar, beliefs, dan perilakunya dalam pembelajaran bahasa. Individu yang tidak memiliki kesulitan dalam mengekspresikan pikirannya dan memahami ide orang lain dalam bahasa pertamanya akan mengalami kesulitan untuk melakukan hal tersebut dalam bahasa asing dan menilai semua itu sebagai ancaman dalam persepsi mereka.

Beliefs yang dimiliki pembelajar tentang pembelajaran bahasa memiliki peran penting dalam proses pembelajaran. Horwitz (1988) menegaskan bahwa 
pembelajar terkadang memiliki belief yang tidak realistis tentang belajar bahasa sehingga itu membuat mereka menjadi cemas. Menurut Young (1991), kecemasan terjadi ketika keyakinan (belief) yang dimiliki dengan kenyataan saling berbenturan misalnya siswa yang percaya bahwa belajar bahasa itu fokus pada menerjemahkan atau menghafalkan kosakata baru tentunya akan mengalami frustrasi dan stress dalam kelas yang berorientasi komunikatif. Sejumlah belief yang dimiliki pembelajar dalam mempelajari bahasa asing juga memberi kontribusi terhadap kecemasan yang dialami dalam pembelajaran bahasa Inggris. Beliefs pada diri siswa diyakini sebagai sumber utama kecemasan dalam pembelajaran bahasa (Young, 1991). Dalam kenyataannya Horwitz (1988) menemukan bahwa sejumlah pembelajar bahasa percaya bahwa belajar bahasa Inggris harus dilakukan dalam situasi yang sebenarnya dan itu harus dilakukan setelah pembelajar benar-benar sudah mampu berbicara dengan lancar. Mereka menganggap pentingnya mampu berbicara dengan aksen yang sempurna dan itu harus diawali dengan proses menerjemahkan dari bahasa Inggris. mereka juga percaya bahwa dua tahun cukup untuk dapat lancar menguasai bahasa asing yang dipelajari. Sayangnya belief itu tidak realistik dan tentunya akan membuat mereka kecewa dan frustrasi sehingga meningkatkan kecemasan mereka dalam mengikuti proses pembelajaran bahasa yang dilakukan. Horwitz (1988) menjelaskan bahwa beliefs yang dimiliki siswa akan membuat mereka merendahkan kemampuan yang dimiliki sehingga itu akan menimbulkan kecemasan.

MacIntyre, Noles, dan Clement (1997) dalam penelitiannya melihat bagaimana persepsi siswa tentang kemampuannya dalam belajar bahasa asing akan memengaruhi tingkat kecemasan yang dialami dalam mengikuti proses belajar. Penelitian terhadap 37 mahasiswa yang mengikuti kelas bahasa Perancis menunjuk- kan adanya hubungan antara kecemasan dalam mempelajari bahasa kedua, persepsi tentang kemampuan yang dimiliki untuk menguasai bahasa yang dipelajari, serta kemampuan sebenarnya yang dimiliki. MacIntyre dkk. (1997) menegaskan bahwa ketika siswa merasa tidak mampu atau takut gagal maka hal itu akan menghasilkan kecemasan. Selanjutnya ketika kecemasan muncul maka siswa menolak untuk berkomunikasi dan jika tidak ada komunikasi maka akan sulit untuk menilai ulang kemampuannya. Sementara penelitian Onwuegbuzie, Bailey dan Daley (1999) menemukan bahwa siswa yang memiliki penilaian yang tinggi akan kemampuan yang dimiliki cenderung rendah tingkat kecemasannya. Cheng dkk. (1999) juga menemukan bahwa persepsi terhadap kemampuan yang dimiliki berpengaruh terhadap kecemasan dalam mengikuti proses belajar bahasa pada mahasiswa Taiwan. Selain itu beliefs yang dimiliki akan menjadi prediktor tinggi rendahnya tingkat kecemasan yang dialami.

Onwuegbuzie dkk. (1999) menemukan tiga aspek dari persepsi terhadap kemampuan yang dimiliki secara signifikan berhubungan dengan kecemasan dalam pembelajaran bahasa asing. Faktor tersebut adalah harapan yang dimiliki terhadap prestasi yang akan dicapai, persepsi terhadap keunggulan diri, serta persepsi tentang kemampuan akademik yang dimiliki. Penelitian itu mendukung apa yang disampaikan Young (1991) bahwa beliefs pembelajar menjadi sumber utama dalam munculnya kecemasan dalam pembelajaran bahasa asing. Truitt (1995), Oh (1996), dan Kuntz (1996) juga telah meneliti hubungan antara beliefs tentang pembelajaran bahasa dengan kecemasan yang dialami dalam mengikuti pembelajaran bahasa asing. Truitt (1995) menemukan bahwa beliefs tentang pembelajaran bahasa dan juga rendahnya self-efficacy menjadi sumber kecemasan dalam pembelajaran bahasa asing. 
Aydin (2001) mengatakan bahwa alasan personal pada diri siswa, sikap guru di kelas, belief yang dimiliki siswa dan prosedur pengajaran pada kelas menulis dan berbicara menjadi empat sumber utama timbulnya kecemasan dalam pembelajaran bahasa asing. Aydin (2001) juga menambahkan bahwa siswa terkadang memiliki ide yang tidak realistis tentang pembelajaran bahasa dan itu memberikan efek negatif pada pencapaian hasil belajar mereka. Ohata (2005) menyimpulkan bahwa jika belief yang dimiliki tidak sesuai dengan situasi sebenarnya maka hal itu akan menimbulkan kecemasan. Belief yang dimiliki siswa tentang pembelajaran bahasa asing akan membentuk cara berpikirnya dan itu menjadi faktor yang memengaruhi kecemasan siswa (Bernat, 2004). Oh (1996) menyimpulkan hubungan yang signifikan antara beliefs dan kecemasan pada pembelajar bahasa Jepang. Kuntz (1996) dan Truitt (1995) juga mendapatkan hasil yang sama dimana pembelajar yang kurang memiliki kepercayaan diri cenderung memiliki kecemasan yang tinggi dalam mengikuti pembelajaran bahasa asing.

Ada beberapa istilah yang digunakan oleh para peneliti mengacu pada kecemasan bahasa asing yaitu language anxiety, foreign language anxiety, dan foreign language learning anxiety. Gardner dan MacIntyre (1993) mengartikan kecemasan dalam pembelajaran bahasa asing adalah ketakutan (fear or apprehension) yang terjadi ketika pembelajar dituntut untuk menggunakan bahasa asing yang dipelajari. Kecemasan bahasa adalah konstruk psikologis yang umumnya lahir dari dalam diri individu (learner's own self) seperti persepsi terhadap diri, orang lain dan situasi yang dihadapi serta belief yang dimiliki tentang pembelajaran bahasa. Para peneliti menggambarkan kecemasan dalam pembelajaran bahasa di kelas sebagai "alarming" dan mereka memperkirakan bahwa setengah dari jumlah pembelajar di kelas bahasa asing mengalami kecemasan (Horwitz dan Young, 1991). Ditambahkan bahwa siswa yang mengalami kecemasan dalam proses pembelajaran akan mengalami kesulitan dalam upaya memproses bahasa dan akhirnya berdampak pada kurangnya pemahaman atau pencapaian siswa. Kecemasan bahasa menduduki peringkat yang tinggi diantara sejumlah faktor yang memengaruhi pembelajaran bahasa bagaimanapun setting pembelajarannya (Oxford, 1999). Penelitian Gardner dan MacIntyre (1992) menyimpulkan bahwa kecemasan dalam pembelajaran bahasa asing dialami oleh lebih dari sepertiga pembelajar dengan hasil sekitar $44 \%$ pembelajar merasa takut ketika mereka tidak memahami bahasa yang dipelajari. Disimpulkan juga bahwa hanya $21.4 \%$ mengaku takut ketika mereka tidak mengerti apa yang dikatakan gurunya yang mungkin juga karena mereka takut terhadap gurunya. Hasil lainnya kecemasan juga disebabkan oleh evaluasi yang diberikan oleh temannya (Liu dan Jackson, 2008). Dalam penelitian itu disimpulkan 30\% siswa memikirkan tentang penilaian siswa lain terhadap dirinya dan merasa bahwa dirinya tidak sebaik teman lain. MacIntyre (1999) menjelaskan bahwa kecemasan dalam pembelajaran akan selalu ada namun tidak konsisten sifatnya karena akan tergantung pada situasi yang dihadapi.

Ohata (2005) menjabarkan bahwa kecemasan bahasa adalah fenomena psikologis yang kompleks karena dipengaruhi oleh banyak faktor yang berbeda. Menurut Bandura (1997) kecemasan adalah konstruk yang berhubungan dengan self-efficacy yaitu penilaian individu terhadap kemampuannya untuk melakukan tugas yang dihadapi dan itu berperan dalam menimbulkan kecemasan dalam pembelajaran bahasa. Survei yang dilakukan Aida (1994) menyimpulkan bahwa siswa yang memiliki kecemasan bahasa tinggi adalah mereka yang memiliki penilaian diri yang rendah terhadap kemampuan yang dimiliki. Sejumlah penelitian juga menyimpulkan adanya hubungan negatif antara kecemasan bahasa 
dengan self-efficacy atau penilaian terhadap kemampuan diri (Maclntyre, Noels dan Clement 1997). Young (1991) menegaskan bahwa tingkat penilaian individu terhadap kemampuannya (self-efficacy) berhubungan dengan kecemasan bahasa. Siswa yang memiliki self-efficacy yang rendah memiliki kecemasan dalam melakukan interaksi dengan temannya dan menjadi lebih sensitif terhadap pemikiran dan penilaian orang lain. Tremblay dan Gardner (1995) juga menyimpulkan self-efficacy yang rendah cenderung mengakibatkan kecemasan bahasa yang tinggi.

Efek dari self-efficacy yang tinggi menghasilkan kestabilan dalam mengerjakan tugas, strategi menyelesaikan masalah dan menurunnya kecemasan dalam mengikuti proses pembelajaran. Tokoh lainnya Smith dan Kirby (2001) menjelaskan bahwa sebagai pencetus emosi, selfefficacy mempunyai peran utama dalam perkembangan dan perbedaan emosi yang terjadi sehingga salah satu emosi yang muncul saat proses belajar adalah kecemasan dalam pembelajaran. Hsieh (2008) menambahkan bahwa self-efficacy memoderatori kecemasan dimana siswa yang memiliki self-efficacy rendah memiliki sikap yang lebih negatif dan kecemasan yang lebih tinggi terhadap pembelajaran bahasa asing yang mereka ikuti. Penelitian Anyadubalu (2010) juga menyimpulkan bahwa self-efficacy tidak memengaruhi pencapaian hasil belajar tetapi self-efficacy secara langsung memengaruhi kecemasan dalam pembelajaran bahasa Inggris. Siswa yang memiliki self-efficacy tinggi akan mengalami kecemasan yang lebih rendah daripada mereka yang memiliki self-efficacy rendah.

Csikszentmihalyi (1997) dengan teori flow mengatakan bahwa pembelajar yang memiliki self-efficacy tinggi cenderung memiliki pengalaman positif dalam pembelajaran bahasa. Self-efficacy yang rendah digambarkan dengan hubungan tingkat kecemasan yang tinggi serta adanya motivasi menghindar dan tentunya akan mengarahkan pada tingkat pengalaman. Carver (2006) menggambarkan bahwa emosi positif yang dikembangkan dari kondisi pengalaman belajar yang positif dapat meningkatkan self-efficacy. Demikian sebaliknya dengan emosi dan pengalaman negatif yang dimiliki siswa dalam proses pembelajaran maka itu akan mendorong rendahnya tingkat self-efficacy. Dengan kata lain self-efficacy yang tinggi akan menurunkan tingkat kecemasan dan membuat motivasi meningkat. Secara teori social cognitive Bandura (1993) menjelaskan bahwa self-efficacy berperan penting dalam perilaku coping seperti juga halnya dalam mengerahkan jumlah dan lama usaha dalam proses belajar yang dijalani. Self-efficacy juga berperan dalam motivasi dan perilaku pencapaian hasil belajar sehingga Bandura menyimpulkan bahwa self-effcacy adalah penyebab dari cognitive determinant terjadinya kecemasan. Tokoh lainnya Smith dan Kirby (2001) menjelaskan bahwa sebagai pencetus emosi, self-efficacy mempunyai peran utama dalam perkembangan dan perbedaan emosi yang terjadi sehingga salah satu emosi yang muncul saat proses belajar adalah kecemasan dalam pembelajaran bahasa.

Tremblay dan Gardner (1995) menggambarkan hubungan antara kecemasan bahasa dengan self-efficacy dimana self-efficacy yang rendah memengaruhi kecemasan yang dialami para pembelajar. Pada penelitian berikutnya Gardner, Tremblay dan Masgoret (1997) menegaskan bahwa self-efficacy yang rendah menyebabkan tingginya kecemasan dalam pembelajaran bahasa. Self-efficacy dalam istilah linguistik sering disamakan dengan self-confidence, self-perceptions, atau selfratings. Self-efficacy menjadi faktor kuat dalam keberhasilan pembelajaran bahasa pada mahasiswa yang belajar bahasa Perancis. Hal yang sama dikatakan oleh Zimmerman (2000) bahwa self-efficacy memengaruhi motivasi, ketahanan siswa dalam menghadapi kesulitan belajar 
(persistence) dan juga usaha yang dikerahkan dalam proses belajar. Ketika Tremblay dan Gardner (1995) merumuskan kecemasan bahasa membuat rendahnya self-efficacy, Bandura (1997) menyimpulkan hal sebaliknya yaitu self-efficacy memengaruhi kecemasan karena penilaian diri yang dimiliki siswa terhadap kemampuannya menimbulkan perasan negatif terhadap dirinya. Apapun rumusan hubungan antara self-efficacy dan kecemasan yang dibuat oleh para ahli, self-efficacy dapat dikatakan memiliki peran penting dalam interaksi variabel individu pada keberhasilan pembelajaran bahasa yang dijalani.

Thakur dan Kaur (2013) menyimpulkan hubungan yang negatif dan signifikan antara self-efficacy dengan kecemasan dalam pembelajaran dimana semakin tinggi self-efficacy yang dimiliki siswa semakin rendah tingkat kecemasan yang dialami siswa. Hasil penelitian Woodrow (2006) menggambarkan hubungan selfefficacy dengan kecemasan dalam pembelajaran bahasa Inggris. Tremblay dan Gardner (1995) dalam penelitiannya menunjukkan hubungan variabel kecemasan bahasa dengan self-efficacy dimana selfefficacy yang rendah cenderung mengakibatkan kecemasan bahasa yang tinggi. Hal itu didukung oleh Bandura (1997) yang membuat rumusan bahwa self-efficacy memengaruhi kecemasan. Self-efficacy memengaruhi reaksi afektif dan rendahnya self-efficacy dapat menjadi sumber kecemasan dalam pembelajaran bahasa asing. Hasil penelitian Respati dan Prastomo (2008) menunjukkan hubungan yang negatif antara self-efficacy dengan kecemasan dalam pembelajaran bahasa asing. Simpulan yang dihasilkan adalah semakin tinggi self-efficacy maka kecemasaan dalam bahasa asing semakin rendah. Penelitian Cheng (2001) juga menyimpulkan bahwa siswa yang memiliki tingkat self-efficacy tinggi dalam pembelajaran bahasa asing (mereka percaya bahwa mereka mampu mengerjakan tugas yang diberikan) secara signifikan membuat nilai kecemasan dalam bahasa asing menjadi rendah.

Penelitian lainnya yang mendukung hubungan ini adalah Onwuegbuzie dkk. (1999) yang mengatakan bahwa kecemasan dalam pembelajaran bahasa asing berasal dari keyakinan individu pembelajar seperti self-efficacy. Self-perception siswa terhadap kemampuannya berkontribusi terhadap kecemasan dalam pembelajaran bahasa asing. Ketidakyakinan siswa dalam pembelajaran bahasa asing menjadi sumber kecemasan sehingga siswa yang kurang yakin dengan kemampuannya akan merasakan ketakutan. Penelitian Barrows, Dunn dan Lloyd (2013) melihat hubungan kecemasan dalam pembelajaran bahasa asing dengan self-efficacy namun hasilnya menunjukkan tidak ada hubungan antara keduanya dengan nilai korelasi 1.297. Penelitian Maden (2011) menunjukkan hubungan antara self-efficacy dan kecemasan dalam pembelajaran membaca dan mendengarkan pada mahasiswa semester 3 dan 4 bahasa Perancis. Penelitian lainnya yang juga melihat selfefficacy berhubungan negatif dengan kecemasan dalam pembelajaran bahasa asing (MacIntyre, Clément, Dörnyei, dan Noels, 1997). Kecemasan telah diidentifikasi sebagai faktor penting yang memengaruhi proses pembelajaran bahasa. Kualitas pengalaman belajar yang dialami juga memengaruhi self-efficacy dalam pembelajaran bahasa. Semakin positif pengalaman yang dimiliki akan semakin meningkatkan self-efficacy siswa demikian pula sebaliknya pengalaman yang negatif membuat self-efficacy menjadi rendah.

Self-efficacy yang tinggi membuat tingkat kecemasan menjadi rendah, dan ini artinya pembelajar yang memiliki selfefficacy yang tinggi cenderung memiliki pengalaman belajar yang positif. Sebaliknya self-efficacy yang rendah mengakibatkan tingkat kecemasan yang tinggi dan itu adalah hasil dari pengalaman pembelajaran yang negatif (Csikszentmihalyi, 1997). Tremblay dan Gardner (1995) juga 
menyimpulkan hubungan variabel kecemasan bahasa dengan self-efficacy dimana self-efficacy yang rendah cenderung mengakibatkan kecemasan bahasa yang tinggi. Banyak penelitian yang dilakukan untuk mempelajari tingkat kecemasan pada kelas pembelajaran bahasa asing namun kajian psikologi dan pendidikan di Indonesia tidak banyak yang membahas. Saran dari penelitian Horwitz dan Young (1991) untuk meneliti lebih mendalam tentang variabel afektif seperti motivasi, anxiety dan risk taking juga menjadi alasan untuk melakukan penelitian kecemasan dalam pembelajaran bahasa Inggris.

Penelitian tentang kecemasan dalam pembelajaran bahasa Inggris memang banyak terkait dengan faktor individu tetapi ternyata korelasinya tidak menunjukkan hasil yang konsisten antara beberapa penelitian. Tujuan penelitian ini ingin melihat keterkaitan faktor individu dalam memengaruhi kecemasan dalam pembelajaran bahasa Inggris khususnya pada mahasiswa UIN Sunan Gunung Djati Bandung. Dengan demikian kompleksitas perilaku kecemasan dalam pembelajaran bahasa Inggris dapat dikenali dan diterangkan dinamikanya dalam konteks UIN Sunan Gunung Djati Bandung.

Hipotesis penelitian ini adalah selfefficacy berperan terhadap kecemasan dalam pembelajaran bahasa Inggris, belief berperan terhadap kecemasan dalam pembelajaran bahasa Inggris, motivasi berperan terhadap kecemasan dalam pembelajaran bahasa Inggris serta ketiga faktor individu (self-efficacy, belief dan motivasi) berperan dalam memunculkan kecemasan dalam pembelajaran bahasa Inggris. Keterkaitan antar variabel dalam penelitian ini menunjukkan bahwa kecemasan dalam pembelajaran bahasa Inggris merupakan perilaku yang kompleks dan tidak dapat diterangkan dari satu faktor penyebab saja.

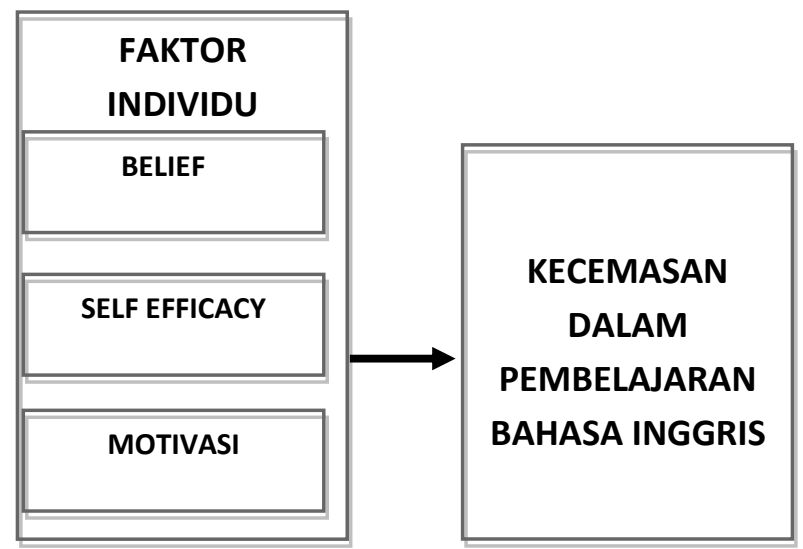

Gambar 1. Hasil meta-analisis kecemasan dalam pembelajaran bahasa Inggris

\section{Metode Penelitian}

\section{Desain}

Desain penelitian ini menggunakan penelitian korelasional yang menjelaskan bahwa selain mendeskripsikan fenomena dari variabel yang diteliti juga mengungkapkan tentang ada tidaknya hubungan antar variabel. Sehubungan dengan jenis penelitian yang digunakan maka akan dilihat hubungan antara variabel independen (prediktor) yaitu self-efficacy (X1), belief (X2), dan motivasi (X3) secara sendiri dan bersama-sama dengan variabel dependen yaitu kecemasan dalam pembelajaran bahasa Inggris. Selain itu juga akan menemukan besarnya sumbangan masingmasing variabel maupun secara bersamasama.

\section{Populasi dan Sampel}

Sejumlah 100 mahasiswa UIN Sunan Gunung Djati Bandung yang berasal dari Fakultas Psikologi dan Fakultas Tarbiyah menjadi partisipan dalam penelitian ini. Adapun karakteristik sampel adalah mahasiswa yang ada pada semester 1 sampai dengan semester 4, mendapatkan mata kuliah bahasa Inggris sebagai mata kuliah dasar umum (MKDU), dan memiliki mata kuliah di luar bahasa Inggris dengan buku referensi dalam bahasa Inggris. Pengambilan sampel menggunakan penarikan acak secara bertingkat yaitu teknik 
pengambilan sampel dengan unit-unit populasi dikelompokkan menjadi kelompokkelompok homogennya. Caranya dengan melakukan penarikan secara acak dua kelas dari setiap semester pada Fakultas Psikologi dan Fakultas Tarbiyah.

\section{Prosedur Penelitian}

Prosedur penelitian merupakan serangkaian tahapan yang menjadi acuan kerja dalam rangka menyelesaikan suatu penelitian. Kegiatan dalam penelitian ini dapat dibagi dalam dua tahap yaitu tahap perencanaan dan tahap pelaksanaan. Pada tahap perencanaan dilakukan penyiapan instrumen yang akan digunakan, memilih kelas untuk uji coba alat ukur dan sampel penelitian, serta menganalisa reliabilitas dan validitas alat ukur. Selanjutnya pada tahap pelaksanaan dilakukan pengambilan data dengan menyebarkan alat ukur yang telah diujicobakan, kemudian mengolah data dan membuat laporan penelitian.

Uji coba instrumen dilakukan kepada 50 mahasiswa yang tidak termasuk sampel penelitian. Hasil uji reliabilitas terhadap skala kecemasan pada pembelajaran bahasa Inggris dalam penelitian ini menggunakan rumus alpha cronbach dan didapatkan nilai 0,850 . Sedangkan untuk instrumen selfefficacy nilai alpha cronbach sebesar 0,855 ; belief 0,895 dan motivasi 0,896 . Sedangkan uji validitas menggunakan content validity untuk melihat sejauhmana butir item mencerminkan ciri atribut yang hendak dihitung (Azwar, 2013). Langkah selanjutnya dilakukan proses seleksi item untuk mendapatkan item-item yang valid. Selain itu juga dilakukan penilaian dari tokoh ahli (professional judgement) untuk membandingkan bahasa dan isi antara skala yang menggunakan bahasa Inggris dengan bahasa Indonesia.

\section{Teknik Analisis}

Untuk menjawab pertanyaan penelitian ini, yaitu peranan faktor individu terhadap kecemasan dalam pembelajaran bahasa
Inggris digunakan teknik analisis statistik regresi ganda (multiple regression).

\section{Hasil Penelitian Dan Pembahasan}

Dari analisis data yang dilakukan terdapat sejumlah hasil interpretasi secara statistik.

Tabel 1

Korelasi antar Variabel

Coefficients $^{\mathrm{a}}$

\begin{tabular}{|c|c|c|c|c|c|c|}
\hline & & \multicolumn{3}{|c|}{$\begin{array}{cc}\text { Unstandardized } & \text { Standardized } \\
\text { Coefficients } & \text { Coefficients }\end{array}$} & \multirow[b]{2}{*}{$\mathrm{t}$} & \multirow[b]{2}{*}{ Sig. } \\
\hline & & B & $\begin{array}{l}\text { Std. } \\
\text { Error }\end{array}$ & Beta & & \\
\hline \multirow[t]{4}{*}{1} & (Const) & -26.194 & 8.648 & & -3.029 & .004 \\
\hline & SE & -.432 & .167 & -.556 & -2.586 & .013 \\
\hline & BEL & .119 & .033 & .180 & 3.547 & .001 \\
\hline & MOT & .853 & .137 & 1.376 & 6.219 & .000 \\
\hline
\end{tabular}

a. Dependent

Variable: FLA

Hasil analisis hubungan X1 dengan $\mathrm{Y}$ didapatkan $\mathrm{t}$ sebesar -2.586 dengan taraf signifikansi sebesar $0,013 \quad(0,013<0,05)$ yang berarti ada hubungan self-efficacy dengan tingkat kecemasan mahasiswa dalam berbahasa Inggris. Nilai korelasi yang negatif memberikan gambaran bahwa semakin tinggi self-efficacy maka kecemasan akan semakin rendah. Sedangkan hasil analisis X2 terhadap Y didapatkan t sebesar 3.547 dengan taraf signifikansi sebesar $0,001 \quad(0,001<0,05)$ yang berarti bahwa ada hubungan antara belief dengan tingkat kecemasan mahasiswa dalam berbahasa Inggris. Dengan kata lain semakin positif belief yang dimiliki mahasiswa terhadap pembelajaran bahasa Inggris maka akan semakin rendah kecemasannya.

Berikutnya adalah hasil analisis hubungan antara X3 dengan Y didapatkan t sebesar 6.219 dengan taraf signifikansi sebesar $0,000 \quad(0,000<0,05)$ yang berarti bahwa ada hubungan antara motivasi dengan tingkat kecemasan mahasiswa dalam berbahasa Inggris. Dari nilai korelasi 
tersebut dapat dikatakan bahwa semakin tinggi motivasi yang dimiliki akan semakin rendah kecemasan yang dialami.

Tabel 2

Analisis Regresi

\begin{tabular}{lllllll} 
ANOVA $^{\mathrm{b}}$ & \multicolumn{1}{c}{} \\
\hline Model & $\begin{array}{l}\text { Sum of } \\
\text { Squares }\end{array}$ & df & $\begin{array}{l}\text { Mean } \\
\text { Square }\end{array}$ & F & Sig. \\
\hline $\begin{array}{l}1 \\
\begin{array}{l}\text { Regres- } \\
\text { sion }\end{array}\end{array}$ & 3974.915 & 3 & 1324.972 & 276.8 & $.000^{\mathrm{a}}$ \\
$\begin{array}{l}\text { Residual } \\
\text { Total }\end{array}$ & 220.205 & 46 & 4.787 & & \\
\hline
\end{tabular}

Adapun hasil analisis regresi ganda untuk melihat pengaruh $\mathrm{X} 1, \mathrm{X} 2$ dan $\mathrm{X} 3$ secara bersama-sama terhadap Y, didapatkan hasil $F$ sebesar 276.782 dengan taraf signifikansi sebesar $0,000 \quad(0,000<0,05)$ yang berarti ada hubungan yang signifikan antara self-efficacy, belief dan motivasi secara bersama-sama dengan kecemasan mahasiswa dalam belajar bahasa Inggris. Dengan kata lain dapat dikatakan bahwa self-efficacy, belief dan motivasi yang dimiliki mahasiswa memberikan kontribusi terhadap kecemasan yang dirasakan.

Tabel 3

Pengaruh Self-efficacy, Belief, dan Motivasi terhadap Kecemasan.

\begin{tabular}{|c|c|c|c|c|}
\hline \multicolumn{5}{|c|}{ Model Summary } \\
\hline Model & $\mathrm{R}$ & $\begin{array}{c}\mathrm{R} \\
\text { Square }\end{array}$ & $\begin{array}{c}\text { Adjusted R } \\
\text { Square }\end{array}$ & $\begin{array}{l}\text { Std. Error of the } \\
\text { Estimate }\end{array}$ \\
\hline 1 & $.973^{\mathrm{a}}$ & .948 & .944 & 2.18793 \\
\hline
\end{tabular}

Gambaran hasil terakhir adalah sumbangan efektif antara self-efficacy, belief dan motivasi terhadap kecemasan sebesar 94,8\% dan sisanya dipengaruhi oleh faktor lain.

\section{Pengaruh Self-efficacy terhadap Kece- masan dalam Pembelajaran Bahasa Inggris}

Self-efficacy dikatakan oleh Bandura (1993) adalah penilaian akan kemampuan diri dan itu akan membentuk usaha untuk melakukan strategi pembelajaran yang dilakukan. Pengalaman belajar yang positif membuat self-efficacy individu meningkat karena pengalaman akan keberhasilan adalah merupakan salah satu sumber pembentuk self-efficacy. Pembelajar yang memiliki self-efficacy tinggi merasa yakin bahwa dirinya mampu menguasai bahasa asing yang dipelajari meskipun menghadapi berbagai kesulitan. Pembelajar akan menjadi individu yang berusaha mencari strategi belajar yang cocok untuk dirinya. Pembelajar yang memiliki self-efficacy rendah menunjukkan beberapa gejala misalnya bingung dengan pengucapan kosakata bahasa Inggris yang berbeda dari tulisannya. Hsieh (2008) mengatakan bahwa dengan self-efficacy yang rendah membuat pembelajar memiliki sikap yang negatif terhadap pembelajaran bahasa Inggris yang diikuti. Akibatnya adalah kecemasan yang tinggi karena mereka merasakan kebingungan dalam segala hal baik untuk memahami apa yang diucapkan orang lain maupun apa yang harus diucapkan.

Young (1991) menegaskan bahwa pembelajar yang memiliki self-efficacy rendah karena menilai rendah kemampuannya akan mengalami kecemasan dalam melakukan interaksi dengan temannya dan menjadi lebih sensitif terhadap pemikiran dan penilaian orang lain. Mereka takut salah dalam menggunakan bahasa Inggris baik secara lisan maupun tulisan, tidak percaya diri dan takut ditertawakan jika melakukan kesalahan. Ungkapan tersebut adalah salah satu kondisi yang dikatakan Liu dan Jackson (2011) dimana penilaian dari pembelajar lain terhadap dirinya akan menjadi pikiran yang membuat kecemasan untuk menyampaikan apa yang bisa dikatakan. Selain itu penilaian diri bahwa dirinya tidak sebaik teman lain juga ikut memengaruhi kecemasan yang dirasakan. Ketakutan akan evaluasi dalam bentuk apapun juga menjadi penyebab kecemasan dalam pembelajaran bahasa Inggris seperti yang disampaikan Yaili (2012) bahwa pembelajar yang memikirkan tentang 
penilaian orang lain terhadap dirinya membuat mereka menganggap kemampuan yang dimiliki tidak sebaik pembelajar lainnya.

Ada hal lain yang juga membuat selfefficacy pembelajar meningkat atau sebaliknya yaitu penilaian terhadap metode pengajaran yang dianggap sulit untuk diikuti. Model pengajaran yang diterapkan oleh pengajar ikut berkontribusi menimbulkan kecemasan pada pembelajar karena pembelajar merasa dirinya tidak mampu untuk memenuhi apa yang menjadi tuntutan pengajar. Pengajar yang sulit ditebak, kuis yang sering diberikan secara mendadak digambarkan oleh Kitano (2001) menimbulkan kecemasan pada pembelajar. Sikap pengajar seharusnya menciptakan lingkungan sosial yang hangat dengan memilih metode pengajaran yang sesuai dengan kondisi pembelajar yang ada. Jika lingkungan dan suasana pembelajaran yang dijalani pembelajar nyaman maka itu akan membuat self-efficacy mereka meningkat dan kecemasan yang mereka rasakan pun akan menurun.

Ada sejumlah faktor yang disampaikan Worde (2003) dapat meningkatkan kecemasan dalam kegiatan pengajaran serta membuat kondisi self-efficacy pembelajar menjadi menurun. Pertama adalah pengalaman belajar yang tidak menyenangkan dan itu akan tersimpan dalam memori siswa. Tugas pengajar adalah merancang kegiatan pembelajaran agar menarik dan membuat pembelajar mudah untuk memahami apa yang dipelajari. Kemampuan bahasa adalah menguasai empat keterampilan dasar yaitu mendengarkan, berbicara, membaca dan menulis. Keempat keterampilan tersebut tidak hanya pasif sifatnya tetapi juga dituntut untuk produktif seperti berbicara dan menulis. Latihan adalah kunci utama pembelajaran bahasa karena semua keterampilan itu harus mendorong pembelajar untuk aktif mencoba dan melakukan sendiri apa yang telah disampaikan. Tentunya faktor pengajar seperti yang dikatakan Worde (2003) merupakan salah satu kunci dalam kelas. Sikap pengajar dalam menciptakan lingkungan belajar yang hangat tentunya akan sangat membantu meminimalkan potensi munculnya kecemasan pada diri pembelajar.

\section{Pengaruh belief terhadap kecemasan dalam pembelajaran bahasa Inggris}

Apa yang ada dalam persepsi pembelajar seperti materi yang sulit dimengerti, kosakata yang sulit untuk dihafalkan, aturan grammar yang sulit untuk digunakan adalah kondisi yang memicu kecemasan dalam mengikuti pembelajaran bahasa yang dijalani. Harapan yang tidak sama dengan apa yang ditemui pada kenyataan memicu kecemasan. Hal itu juga yang dikatakan Liu dan Jackson (2011) bahwa persepsi pembelajar tentang bahasa asing serta harapan yang dimiliki menjadi faktor yang membuat pembelajar cemas dalam mengikuti kelas bahasa. Ada kemungkinan pembelajar memiliki pengalaman sebelumnya sehingga membentuk sejumlah persepsi tersebut namun tentu saja kondisi itu merugikan pembelajar. Jika pembelajar mengalami kecemasan dalam pembelajaran bahasa maka itu akan mengganggu pencapaian yang didapatkan baik dari segi pemahaman maupun dalam penguasaan bahasa yang dipelajari.

Huang (2010) juga mengatakan bahwa ketika pembelajar tidak dapat memahami pesan yang disampaikan, mereka merasa tidak nyaman dan itu berkembang menjadi kecemasan dalam mengikuti pembelajaran selanjutnya. Pemahaman terhadap apa yang disampaikan secara lisan maupun yang dapat dibaca dalam tulisan merupakan kunci komunikasi. Namun jika kedua hal itu sulit untuk dipahami tentunya akan menjadi kendala dalam berinteraksi pada sejumlah kegiatan pembelajaran yang dirancang. Ada belief lain yang dimiliki pembelajar terutama pada tingkat pendidikan formal seperti sekolah menengah pertama dan atas yaitu seringkali menganggap bahasa Inggris adalah mata pelajaran yang bukan favorit. Akibatnya adalah pembelajar menjalani kegiatan 
pembelajaran dengan frustrasi dan itu menyebabkan kecemasan. Belief yang dimiliki pembelajar menurut Young (1991) menjadi sumber utama munculnya kecemasan dalam pembelajaran bahasa Inggris.

Selain belief yang ada pada diri pembelajar, ada pula belief yang dimiliki pengajar dan itu juga berkontribusi terhadap munculnya kecemasan pada pembelajar. Young (1991) mengatakan bahwa instructur belief seperti sedikit intimidasi dan menunjukkan otoritatif sering dilakukan pengajar agar perannya di kelas diakui oleh pembelajar dan mereka didengarkan saat berbicara. Penanaman belief itu juga banyak terjadi di dalam kelas pembelajaran bahasa asing akibatnya adalah kecemasan pada pembelajar. Pada dasarnya kegiatan sosial dilakukan pembelajar dalam kelas namun pengajar banyak yang tidak suka dengan kegiatan berpasangan atau berkelompok karena dianggap membuat kelas sulit untuk diatur. Ada pula yang menganggap bahasa Inggris bukanlah bahasa ibu sehingga itu menggambarkan ungkapan pembelajar yang menganggap tidak ada kemampuan baginya untuk dapat menguasai bahasa asing sampai seperti bahasa pertamanya. Woodrow (2006) memang menemukan sekelompok etnik budaya tertentu seperti budaya timur yang lebih pencemas dalam mengikuti proses pembelajaran bahasa. Alasan itu sebenarnya dapat menjadi hambatan bagi sebagian pembelajar karena merasa menjadi bagian dari apa yang disampaikan Woodrow (2006) namun jika ada usaha untuk memperbaiki belief yang telah dipegang tersebut maka secara perlahan akan muncul keyakinan bahwa siapapun memiliki kemampuan untuk menguasai bahasa selain bahasa ibunya.

Kebanyakan pembelajar menganggap bahasa Inggris itu sulit untuk dipelajari dengan alasan susah untuk menghafalkan kosakata, format kalimat, tenses dan aturan lainnya. Hal itu membuat mereka takut dengan pelajaran bahasa Inggris dan itu dikatakan oleh Horwitz (1986) bahwa memilih diam lebih baik daripada mencoba menjawab secara lisan dan akan menjadi bahan tertawaan pembelajar lainnya. Pada dasarnya kesalahan dalam kelas bahasa adalah hal yang wajar namun belief itu bertentangan dengan apa yang ada pada diri pembelajar. Mereka tidak mau terlihat bodoh dengan melakukan kesalahan karena menjaga kesan positif adalah hal yang paling penting untuk kalangan pembelajar asia dimana mereka tidak mau kehilangan muka (malu). Hal itu akan semakin membuat kecemasan sehingga akan menghambat keterlibatan pembelajar dalam berbagai kegiatan yang akan melatih kemampuan bahasa mereka.

\section{Pengaruh motivasi terhadap kecemasan dalam pembelajaran bahasa Inggris}

Gardner dan MacIntyre (1993) menjelaskan bahwa kecemasan dan motivasi memiliki hubungan resiprokal dimana kedua variabel tersebut saling memengaruhi. Pengajar yang galak seperti kasar dalam sikap dan ucapan adalah kondisi yang biasanya dihadapi pembelajar sehingga itu menjadi alasan bagi mereka untuk tidak menyukai pelajaran bahasa Inggris. Liu dan Jackson (2011) juga mengatakan bahwa pembelajar mengaku takut ketika mereka tidak mengerti apa yang dikatakan gurunya yang mungkin juga itu adalah akibat dari perasaan takut terhadap gurunya. Gardner (2007) mengartikan motivasi sebagai dorongan dalam berbagai situasi dan membedakan dua perspektif yang berbeda. Perspektif pertama adalah motivasi sebagai atribut internal dan atribut eksternal yang berarti bahwa individu dapat dimotivasi dengan dorongan dari luar diri contohnya upaya pengajar untuk memotivasi siswanya. Namun Gardner (1997) menegaskan bahwa setiap pembelajar pasti sudah memiliki potensi yang bisa didorong dari luar. Yan dan Horwitz (2008) juga mengatakan bahwa faktor pemicu kecemasan pembelajar dalam kelas adalah guru yang 
meliputi kepribadiannya yang kurang ramah serta keterampilannya dalam mengajar seperti dalam hal pemilihan strategi belajar yang sesuai dengan kondisi pembelajar. Selain itu pengaturan kelas yang dilakukan oleh guru baik itu kegiatan yang dirancang maupun materi yang disampaikan. Ewald (2007) mengatakan karakter guru dapat menciptakan lingkungan belajar yang nyaman serta memfasilitasi kepercayaan diri pembelajar menjadi meningkat. Namun jika sebaliknya sikap guru bukannya membantu kepercayaan malah justru membuat pembelajar menjadi cemas. Hal yang sama juga dikatakan Liu dan Jackson (2008) dimana pembelajar takut terhadap gurunya karena perilaku pengajar yang kasar atau dingin memberikan efek penting pada pembelajar yaitu munculnya kecemasan.

Malu dan tidak mau dianggap bodoh oleh orang lain merupakan hal yang sangat dihindari dan itu adalah komponen kecemasan dalam pembelajaran bahasa asing. Horwitz (1986) menjelaskan tentang ketakutan pada evaluasi sehingga pembelajar jarang melakukan komunikasi dan interaksi dengan orang lain menggunakan bahasa asing yang dipelajari. Khattak, Jamshed, Ahmad dan Baig (2011) mengatakan bahwa pada konteks Asia masyarakatnya sangat menjaga konsep "losing face" sehingga terkadang pengajar yang mempermalukan siswa atau dengan melakukan bully terhadap pembelajar akan membuat mereka semakin cemas. Gardner (1997) menegaskan bahwa setiap pembelajar pasti sudah memiliki potensi yang bisa didorong dari luar. Gardner (1997) menjelaskan dengan "integrative motive," dimana salah satu variabelnya adalah sikap terhadap proses pembelajaran yang tercermin dalam keinginan untuk belajar dan usaha yang dimiliki.

Menurut MacIntyre (2001) pembelajar yang termotivasi akan memiliki tiga elemen yaitu usaha untuk belajar, keinginan untuk belajar bahasa, dan perasaan positif ketika mengerjakan tugas yang diberikan.
MacIntyre dan Gardner (1991) juga berpendapat bahwa motivasi dan sikap adalah faktor paling dominan dalam proses belajar bahasa. Jika pembelajar memiliki pengalaman negatif maka kecemasan terhadap bahasa yang dipelajari akan sering terjadi dan memengaruhi pembelajaran. Ada pembelajar yang menganggap bahasa Inggris bukan bahasa sehari-hari sehingga menganggap kegiatan menggunakan bahasa Inggris adalah kondisi yang memaksakan dan membuat mereka tidak menikmati kegiatan belajarnya. Ada pula pembelajar yang tidak memiliki goal sehingga motivasi rendah tidak berusaha mencari cara supaya bisa menguasai bahasa asing yang dipelajari. Misalnya dengan motivasi tinggi ada strategi menempelkan kosakata pada benda yang ada di sekitarnya.

Metode pengajaran merupakan salah satu faktor yang disampaikan Worde (2003) memberikan kontribusi terhadap munculnya kecemasan dalam kegiatan speaking. Grammar yang selalu disampaikan pengajar dengan tidak memodifikasi ragam kegiatan akan membuat jenuh sehingga pembelajar menganggap bahwa mereka tidak akan dapat menguasai bahasa Inggris sampai kapanpun karena sulitnya grammar yang disampaikan pengajar. Selain itu metode menerjemahkan dalam proses belajar bahasa dan penekanan pada aturan-aturan grammar membuat pembelajar takut untuk berbicara. Mereka tidak tinggal di lingkungan yang mendukung pembelajaran bahasa Inggris atau dengan kata lain tidak ada pembiasaan menggunakan bahasa Inggris. Liando dkk. (2005) mengatakan bahwa status bahasa Inggris di Indonesia adalah masih sebagai bahasa asing sehingga hal itu membuat masyarakat Indonesia tidak menggunakan bahasa Inggris secara aktif dan meluas dalam komunikasi baik lisan maupun tulisan. Namun bahasa Inggris bagi sebagian daerah tidak bisa digunakan dalam komunikasi karena peran bahasa daerahnya masih sangat kuat. Pada akhirnya motivasi mendapatkan nilai yang lebih menonjol 
karena hanya untuk lulus dari setiap tingkat di lembaga pendidikan formal.

\section{Pengaruh faktor individu (self-efficacy, belief dan motivasi) terhadap kecemasan dalam pembelajaran bahasa Inggris}

Oxford (1992) mengatakan bahwa faktor individu yaitu motivasi dan belief sangat berperan dalam pembelajaran bahasa asing. Sebagian besar pembelajar menganggap bahasa Inggris itu susah dan sepertinya pengalaman sebelumnya membentuk belief negatif dalam mindset mereka. Akibatnya mereka menjadi tidak percaya diri akan kemampuan untuk bisa menguasai bahasa asing yang dipelajari. Hal itu pernah dikatakan Aida (1994) bahwa konstruk kecemasan berasal dari penilaian diri yang rendah terhadap kemampuan yang dimiliki. Selain itu persepsi tentang kesulitan terhadap bahasa Inggris yang dipelajari menurut Oh (1996) memengaruhi tingkat keyakinan pembelajar sehingga mereka akan memiliki penilaian yang rendah tentang kemampuan yang dimiliki. Penilaian diri tersebut akan menurunkan motivasi dalam mempelajari bahasa Inggris dan juga strategi belajar yang dipilih.

Kurangnya usaha yang dilakukan dalam upaya menguasai bahasa asing yang dipelajari menunjukkan kurangnya motivasi yang dimiliki. Terkadang pembelajar memiliki keinginan yang besar untuk bisa menguasai bahasa Inggris namun kondisi di luar dirinya seperti metode pengajaran yang dilakukan pengajar serta suasana belajar yang dihadapi membuat motivasi mereka menurun. Ditambah dengan sikap pengajar yang kurang menghargai perbedaan yang ada pada pembelajar seperti belief negatif yang dimiliki serta kurangnya motivasi untuk mencari cara belajar yang cocok dengan gaya belajarnya. Seperti apa yang dikatakan Gardner (2007) bahwa ketika seseorang termotivasi maka ia akan memiliki alasan untuk terlibat dalam kegiatan-kegiatan yang relevan, melakukan usaha, tidak mudah menyerah, serta menunjukkan keinginan belajar dan menikmatinya. Namun apa yang dihadapi pembelajar adalah hanya sebatas keinginan untuk mampu menguasai bahasa Inggris yang dipelajari belum diiringi dengan usaha yang keras untuk mempelajarinya.

Kegiatan pembelajaran termasuk metode pengajaran yang digunakan juga menjadi faktor yang berkontribusi terhadap tinggi rendahnya motivasi yang ada pada pembelajar. Seringkali pola belajar yang diterapkan pengajar adalah memaksa pembelajar untuk menguasai grammar dan menghafalkan kosakata sehingga membuat pembelajar terkadang jenuh dan tidak dapat merasakan makna dari belajar bahasa itu sebagai alat untuk komunikasi. Hal itu yang juga disampaikan Worde (2003) bahwa kegiatan pengajaran yang tidak memperkenalkan fungsi dari bahasa itu sendiri akan membuat pembelajar merasa tidak ada motivasi untuk menguasai bahasa asing yang dipelajari sehingga hasil akhir yang dirasakan adalah kecemasan dalam mengikuti metode pembelajaran yang diterapkan pengajar seperti menghafalkan kosa kata dan aturan grammar.

Mari dan Gumel (2015) mengatakan bahwa penilaian pengajar tentang ketidakmampuannya mengatasi berbagai tugas akademik menimbulkan krisis kepercayaan dan krisis akademik. Jika pembelajar merasa tidak mampu melakukan tugas yang diberikan maka motivasi untuk mencari cara mengerjakan tugas pun akan sulit untuk dimiliki. Pada akhirnya kondisi cemas dalam mengikuti proses pembelajaran bahasa asing yang dipilih pun akan semakin memengaruhi. Pembelajar yang cemas tentunya akan ketakutan dengan segala bentuk kegiatan yang mengharuskan menggunakan bahasa Inggris dalam kegiatan belajarnya.

Belief yang dimiliki tentang kesalahan yang dibuat dalam pengucapan dan tulisan membuat pembelajar takut untuk mencoba dalam proses latihan. Kondo dan Yin-Ling (2004) menegaskan bahwa faktor yang berkontribusi pada kecemasan dalam pembelajaran bahasa asing diantaranya 
takut gagal, takut salah, model pengajaran guru dan kurang percaya diri. Ketidakpercayaan diri dirasakan dalam sejumlah kegiatan seperti tidak paham pertanyaan guru, tidak tahu cara menjawab pertanyaan guru, sehingga merasa khawatir dengan kemampuannya.

Bahasa Inggris memang memiliki keunikan karena penulisan dan pengucapannya yang berbeda sehingga hal itu dianggap sesuatu yang menjadikan bahasa Inggris sulit untuk dipelajari. Liu dan Jackson (2008) mengatakan bahwa pembelajar takut ketika mereka tidak mengerti apa yang dikatakan gurunya. Hal lain yang mungkin terjadi karena kurangnya perbendaharaan kata yang dimiliki.

Pengalaman belajar sebelumnya yang kurang baik tentunya akan melekat pada ingatan pembelajar dan itu seringkali membangun belief negatif tentang pembelajaran selanjutnya yang diikuti. Jika pembelajar merasa proses belajar bahasa itu adalah sesuatu yang penuh dengan kesulitan dan tidak mungkin untuk bisa dilakukan tanpa adanya kemampuan atau bakat khusus, maka itu akan membuat selfefficacy pembelajar menjadi rendah. Mereka akan menganggap dirinya tidak mampu untuk mengerjakan berbagai tugas yang ada dalam proses belajar serta merasa tidak memiliki kemampuan seperti pembelajar lainnya. Salah satu kondisi yang dijumpai dalam kelas belajar bahasa Inggris adalah bully ketika melakukan kesalahan. Bully dirasakan juga dari pengajar karena dianggap tidak dapat memberikan jawaban yang benar oleh guru. Khattak dkk. (2011) mengatakan cara pengajar menanggapi kesalahan yang dibuat pembelajar serta sikap yang kaku dalam mengajar menciptakan lingkungan pembelajaran yang membuat stress pada pembelajar. Hal yang sama juga dikatakan Aida (1994) bahwa perilaku guru menjadi salah satu faktor yang paling menonjol sebagai penyebab kecemasan dalam pembelajaran bahasa di kelas. Contohnya adalah cara guru mengoreksi kesalahan yang dilakukan pembelajar memberikan pengalaman yang menimbulkan trauma. Kesalahan dalam proses belajar adalah hal yang wajar dan harus dimaklumi serta disikapi dengan baik oleh pengajar. Namun terkadang sikap kasar pengajar dalam mengkritik apa yang dilakukan pembelajar akan menyebabkan kecemasan. Selain itu sikap guru yang dingin, sulit ditebak dan memberikan quiz mendadak juga menjadi faktor penyebab timbulnya kecemasan dalam diri pembelajar.

Faktor lainnya yang juga memengaruhi pembelajar dalam mengikuti pembelajaran bahasa asing adalah ketidakpercayaan diri para pembelajar yang membuat kecemasan semakin tinggi karena mereka merasa tidak memiliki kemampuan untuk mengikuti berbagai rancangan pembelajaran yang telah dibuat oleh pengajar. Ohata (2005) mengatakan bahwa kecemasan adalah fenomena psikologis yang kompleks karena dipengaruhi oleh banyak faktor yang berbeda. Kepercayaan diri terhadap kemampuannya oleh Bandura (1997) disebut konstruk self-efficacy dan jika selfefficacy rendah maka menurut Tremblay dan Gardner (1995) juga akan mengakibatkan kecemasan yang tinggi dalam pembelajaran. Rasa tidak percaya diri terhadap kemampuan yang dimiliki menimbulkan konsekuensi gagal, panik serta tidak yakin dengan apa yang disampaikan dalam proses latihan menggunakan bahasa yang dipelajari.

Keyakinan pembelajar tentang dirinya mampu mengikuti pembelajaran bahasa Inggris memengaruhi besarnya usaha yang dilakukan dan lamanya waktu untuk melakukan tugas yang dihadapi termasuk menghadapi berbagai tugas, rintangan dan kegagalan. Menurut Bandura (1997) jika seseorang meyakini dirinya tidak memiliki kekuatan untuk menghasilkan sesuatu maka mereka tidak akan berusaha untuk mewujudkan sesuatu untuk dicapai. Mereka juga memiliki sikap positif terhadap proses belajar, memiliki kebutuhan terhadap prestasi dan memiliki motivasi intrinsik. 
Selain itu Bandura (1997) menambahkan bahwa mereka juga memiliki keinginan akan hubungan sosial dan kemandirian dalam belajar.

\section{Simpulan dan Saran}

\section{Simpulan}

Variabel X1, X2 dan X3 masingmasing menunjukkan hubungan yang signifikan dengan Y. Demikian pula secara bersama- sama variabel $\mathrm{X} 1, \mathrm{X} 2$ dan $\mathrm{X} 3$ juga berhubungan dengan Y.

Self-efficacy yang rendah membuat tingkat kecemasan mahasiswa dalam pembelajaran bahasa Inggris tinggi. Hubungan antara belief dengan tingkat kecemasan mahasiswa dalam berbahasa Inggris juga signifikan dimana semakin positif belief yang dimiliki mahasiswa terhadap pembelajaran bahasa Inggris maka akan semakin rendah kecemasan-nya.

Hasil lainnya adalah adanya hubungan yang signifikan antara motivasi dengan tingkat kecemasan mahasiswa dalam berbahasa Inggris dimana semakin tinggi motivasi mahasiswa akan membuat rendah kecemasannya dalam pembela-jaran bahasa Inggris.

Hasil analisis regresi ganda menunjukkan bahwa self-efficacy, belief, dan motivasi secara bersama-sama berhubungan dengan kecemasan mahasiswa dalam belajar bahasa Inggris.

\section{Saran}

Kecemasan yang bersumber dari selfefficacy mahasiswa dapat dibantu dengan menciptakan suasana pembelajaran yang tidak menegangkan. Dosen bisa menggunakan cooperative learning sebagai alternatif model pembelajaran yang dapat menurunkan kecemasan mahasiswa. Secara teoretis dalam kelompok kecil individu akan memiliki kesempatan lebih besar dalam berinteraksi dan mengurangi ketegangan. Selain itu bisa dengan membentuk kelompok belajar atau sistem mentor dimana di luar kelas pun kelompok itu bisa berjalan dalam upaya membaca referensi atau belajar memahami bacaan bersama. Iklim belajar dimana dosen banyak bicara dalam kelas sebaiknya juga sedikit diubah menjadi "student centered" agar mahasiswa merasakan bagaimana kemandirian dalam proses belajar. Pemahaman konsep materi memang harus diluruskan oleh dosen namun tidak berarti dosen banyak mengambil waktu dan kesempatan mahasiswa untuk belajar memahami bersama dengan meningkatkan kemampuan mereka terutama dalam keterampilan bahasa Inggris.

Sementara itu kecemasan yang berasal dari belief yang negatif terhadap pembelajaran bahasa Inggris dapat dilakukan sejumlah cara untuk membantu mahasiswa. Iklim akademik di UIN Sunan Gunung Djati Bandung bisa dibuat menjadi ramah bahasa Inggris seperti adanya kelompok-kelompok bahasa yang belajar bersama. Dosen selain pengajar bahasa Inggris juga membantu mengarahkan mahasiswa untuk menerapkan keterampilan membaca. Alternatif kelompok belajar membaca bisa diadakan oleh pusat bahasa sehingga apa yang dibutuhkan mahasiswa yaitu bagaimana cara membaca bacaan bahasa Inggris dapat terbantu. Belief yang negatif mungkin terbentuk dari pengalaman sebelumnya baik di sekolah menengah pertama atau atas, sehingga banyak yang menganggap bahasa Inggris itu sulit untuk dipelajari. Perubahan belief dapat dilakukan oleh kampus UIN Sunan Gunung Djati Bandung dengan cara menghidupkan pusat bahasa di setiap fakultas sehingga akan ada kelompok belajar setidaknya untuk keterampilan membaca saja.

Kecemasan yang berasal dari rendahnya motivasi dapat dilakukan beberapa upaya untuk membangkitkan motivasi para mahasiswa dalam belajar bahasa Inggris. Program yang bersifat internasional bisa membangkitkan motivasi mahasiswa untuk banyak melibatkan diri dengan bahasa Inggris. Kajian bersama, seminar, maupun pertukaran mahasiswa dapat menjadi penyemangat mahasiswa untuk terus 
membekali diri dengan perbaikan kemampuan bahasa Inggris yang dimiliki. Selain itu program pengujian kemampuan bahasa Inggris juga perlu terus diaktifkan agar mahasiswa terpacu dengan kebutuhan akan kemampuan bahasa Inggris terutama dalam memahami informasi yang banyak beredar di era globalisasi ini.

Adapun kecemasan yang berasal dari rendahnya self-efficacy, belief negatif yang dimiliki serta rendahnya motivasi para mahasiswa selayaknya menjadi perhatian semua dosen karena tidak hanya menjadi tanggung jawab dosen bahasa Inggris tetapi juga semua dosen. Bahan materi yang banyak dalam referensi bahasa Inggris menuntut mahasiswa untuk memiliki keterampilan membaca dan memahami apa yang mereka baca. Jika mahasiswa mengalami ketakutan tidak dapat memahami bacaan yang dihadapi, maka kelompok belajar dapat diaktifkan di semua fakultas agar iklim akademik yang mengarah pada collaborative learning dapat diterapkan.

\section{Daftar Pustaka}

Aida, Y. (1994). Examination of Horwitz, Horwitz, and Cope's Construct of Foreign Language Anxiety: The Case of Students of Japanese, Modern Language Journal, 78(1), 155-68.

Anyadubalu, C. (2010). Self-Efficacy, Anxiety, and Performance in the English Language among MiddleSchool Students in English Language Program in Satri Sri Suriyothai School Bangkok, International Journal of Human and Social Studies, 5(3), 193198.

Aydin, B. (2001). A study of Sources of Foreign Language Classroom Anxiety in Speaking and Writing Classes, Unpublished doctoral dissertation, Anadolu University, Eskişehir.

Azwar, S. (2013). Penyusunan Skala Psikologi Edisi 2, Yogyakarta: Pustaka Pelajar.
Bahrien, B. \& Ardianty, S. (2017). Pengaruh Efektivitas Terapi SelfHealing Menggunakan Energi Reiki terhadap Kecemasan Menghadapi Ujian Skripsi, Psympathic, 4(1), 141148.

Bandura, A. (1993). Perceived SelfEfficacy in Cognitive Development and Functioning, Educational Psychologist, 28(2), 117-148.

Bandura, A. (1997). Self-Efficacy: The Exercise of Control, New York: Freeman.

Barrows, J., Dunn, S., \& Lloyd, C.A. (2013). Anxiety, Self-Efficacy, and College Exam Grades, Universal Journal of Educational Research, 1(3), 204-208.

Bernat, E. (2004). Investigating Vietnamese ESL Learners' Beliefs about Language Learning, EA Journal, 21(2), 40-54.

Carver, C.S. (2006). Approach, Avoidance, and the Self-Regulation of Affect and Action, Motivation and Emotion, 30(2), 105-110. doi:10.1007/s11031006-9044-7

Casado, M.A. \& Dereshiwsky, M.I. (2001). Foreign Language Anxiety of University Students, College Student Journal, 35(4), 539-550.

Cheng, Y.S. (2001). Learners' Beliefs and Second Language Anxiety, Studies in English Literature and Linguistics, 27(2), 209-223.

Cheng, Y.S., Horwitz, E.K., \& Schallert, D.L. (1999). Language Anxiety: Differentiating Writing and Speaking Components, Language Learning, 49(1), 417-446.

Csikszentmihalyi, M. (1997). Flow: The Psychology of Optimal Experience, Budapest: Akademiai Kiado.

Ewald, J.D. (2007). Foreign Language Learning Anxiety in Upper-Level Classes : Involving Students as Reserachers. Foreign Language Annals, 40 (1), 1-23. 
Gardner, R.C. \& MacIntyre, P.D. (1992). A Student's Contributions to Second Language Acquisition. Part 1: Cognitive Variables, Language Teaching, 25(2), 211-220.

Gardner, R.C. \& MacIntyre, P.D. (1993). A Student's Contribution to Second Language Learning: Part II, Affective Factors, Language Teaching, 26(4), 111.

Gardner, R.C., Tremblay, P.F., \& Masgoret, A.M. (1997). Towards a Full Model of Second Language Learning: An Empirical Investigation, The Modern Language Journal, 81(1), 344-362.

Gardner, R.C. (2007). Motivation and Second Language Acquisition, Porta Linguarum, 8(2), 9-20.

Horwitz, E.K. (1988). The Beliefs about Language Learning of Beginning University Foreign Language Students, The Modern Language Journal, 72(4), 283-294.

Horwitz, E.K. \& Young, D.J. (Eds.). (1991). Language Anxiety: From Theory and Research to Classroom Implications, Englewood Cliffs, NJ: Prentice Hall.

Horwitz E.K., Horwitz, M.B., \& Cope, J. (1986). Foreign Language Classroom Anxiety, The Modern Language Journal, 70(1), 125-133.

Huang, S. \& Eslami, Z. (2010). The Relationship between Teacher and Peer Support and English Language Learners Anxiety, English Language Teaching, 3(1), 1-10.

Immordino-Yang, M.H. \& Damasio, A. (2007). We Feel, Therefore We Learn: The Relevance of Affective and Social Neuroscience to Education, Journal Compilation, International Mind, Brain, and Education Society and Blackwell Publishing, Inc. 1(1), 3-10.

Khattak, I.Z., Jamshed, T., Ahmad, A., \& Baig, M.N. (2011). An Investigation into the Cause of English Language Learning Anxiety in Students at
AWKUM, Procedia Social and Behavioral Sciences, 15(2011), 16001604.

Kitano, K. (2001). Anxiety in the College Japanese Language Classroom, The Modern Language Journal, 85(4), 549566. http://dx.doi.org/10.1111/ 00267902.00125.

Kondo, D.S. \& Ying-Ling, Y. (2004). Strategies for Coping with Language Anxiety: the Case of Students of English in Japan, ELT Journal, 58(2), 258-265.

Kuntz, P.S. (1996). Beliefs about Language Learning: The Horwitz Model, ERIC Document Reproduction Service No. ED 397649.

Liando, N.V.F., Moni, K.B., \& Baldauf, J.R.B. (2005). Student Motivation in Learning English as a Foreign Language in an Indonesian Context. In J. Yamanashi \& I Milojevic (Eds), Researching Identity, Diversity \& Education: Surpassing the Norm (pp.168-179). Tenerife: Post Press.

Liu, M. \& Jackson, J. (2011). Reticence and Anxiety in Oral English Lessons: A Case Study in China. In Jian, L. \& Cortazzi, M. (eds.). Researching Chinese Learners, pp. 119-137, Palgrave Macmillan, Basingstoke.

Liu, M. \& Jackson, J. (2008). An Exploration of Chinese EFL Learners' Unwillingness to Communicate and Foreign Language Anxiety, The Modern Language Journal, 92(1), 7186.

MacIntyre, P.D. \& Gardner, R.C. (1991). Language Anxiety, Language Learning, 41(2), 513-534.

MacIntyre, P.D., Noels, K.A., \& Clément, R. (1997). Biases in Self-Ratings of Second Language Proficiency: The Role of Language Anxiety, Language Learning, 47(2), 265-287.

MacIntyre, P.D. (1999). Language Anxiety: A Review of the Research for Language Teachers. In D.J. Young (Ed.), Affect in Foreign Language and 
Second Language Learning: A Practical Guide to Creating a LowAnxiety Classroom Atmosphere, Boston: McGraw-Hill.

MacIntyre, P.D. (2001). Motivation, Anxiety and Emotion in Second Language Acquisition. In $\mathrm{P}$. Robinson (Ed.). Individual Differences and Instructed Language Learning (pp. 45-68). Amsterdam: John Benjamins.

Maden, S. (2011). Effect of Jigsaw I Technique on Achievement in Written Expression Skill, Educational Sciences: Theory \& Practice, 11(2), 911-917.

Mari, J.S. \& Gumel, S.A. (2015). Effects of Jigsaw Model of Cooperative Learning on Self-Efficacy and Achievement in Chemistry among Concrete and Formal Reasoners in Colleges of Education in Nigeria, International Journal of Information and Education Technology, 5(3), 196-200. DOI: 10.7763/IJIET.2015.V5.501.

Mulyana, A. (2015). Tawakal dan Kecemasan Mahasiswa pada Mata Kuliah Praktikum, Psympathic: Jurnal Ilmiah Psikologi, 2(1), 17-24.

Oh, M-J.T. (1996). Beliefs about Language Learning and Foreign Language Anxiety: A Study of American University Students Learning Japanese, Dissertation Abstracts International, 57(09), 3858A. (UMI No. 9705927).

Ohata, K. (2005). Language Anxiety from the Teacher ${ }^{\mathrm{ee}} \mathrm{s}$ Perspective: Interview with Seven Experienced ESL/EFL Teachers, Journal of Language and Learning, 3(1), 133155.

Onwuegbuzie, A.J., Bailey, P., \& Daley, C.E. (1999). Factors Associated with Foreign Language Anxiety, Journal of Applied Psycholinguistics, 20(1), 217239.

Oxford, R. (1992). Who are our Students? A Synthesis of Foreign and Second Language Research on
Individual Differences with Implications for Instructional Practice, TESOL Canada Journal, 9(1), 30-49.

Oxford, R.L. (1999). Anxiety and the Language Learner: New Insights. In J. Arnold (Ed.), Affect in Language Learning (pp. 58-67). Cambridge: Cambridge University Press.

Hsieh, Pei-Hsuan. (2008). Why Are College Foreign Language Students' Self-efficacy, Attitude, and Motivation so Different?, International Education, 38(1), 1-3. (http//www questia. com).

Phillips, E.M. (1992). The Effects of Language Anxiety on Students' Oral Test Performance and Attitudes, Modern Language Journal, 76(1), 1426.

Pourdayaei, N. \& Laripour, N. (2013). The Relationship between Foreign Language Anxiety and Emotional Intellegence Among Iranian EFL University Students in Bandar Abbas, Journal of Social and Humanities, 1(6), 108-111.

Respati, W.S. \& Prastomo, O.T. (2008). Hubungan antara Self-efficacy dengan Foreign Language Anxiety pada Mahasiswa Universitas Indonusa Esa Unggul, Jurnal Psikologi, 63(2), 1-10, http//www. Portalgaruda.org).

Smith, C.A. \& Kirby, L.D. (2001). Putting Appraisal in Context: Toward a Relational Model of Appraisal and Emotion, Cognition \& Emotion, 23(7), 1352-1372.

Thakur, Meena \& Kaur, Pushpinder. (2013). The Relationship Between Self-Efficacy and Anxiety in Secondary School Students Across Gender Group, International Journal of Behavioral Social and Movement Sciences, 2(1), 144-148.

Tremblay, P.F. \& Gardner, R.C. (1995). Expanding the Motivation Construct in Language Learning, The Modern Language Journal, 79(2), 505-520. 
Truitt, S.N. (1995). Anxiety and Beliefs about Language Learning: A Study of Korean University Students Learning English, Dissertation Abstracts International, 56(06), 2155A. (UMI No.9534977).

Woodrow, L. (2006). Anxiety and Speaking English as a Second Language, RELC journal, 37(3), 308-328.

Worde, R.V. (2003). Students' Perspectives on Foreign Language Anxiety, Inquiry, 8(1), 21-30.

Yayli, D. (2012). University Summer School Students' Foreign Language Anxiety Levels, Procedia Social and Behavioral Sciences, 46(1), 14011405.

Young, D.J. (1991). Creating a LowAnxiety Classroom Environment: What does Language Anxiety Research Suggest?, Modern Language Journal, 75(1), 426-439.

Zimmerman, B.J. (2000). Self-Efficacy: An Essential Motive to Learn, Contemporary Educational Psychology, 25(2), 82-91. 